\title{
Political Connection, Ownership Structures and Tax Aggressiveness: The Case of Indonesia
}

\author{
Agita Zafi Rahmasari $^{1 *}$, Agung Nur Probohudono ${ }^{2}$, and Doddy Setiawan ${ }^{3}$ \\ 1,2,3 Universitas Sebelas Maret, Solo, Indonesia
}

\begin{abstract}
The main purpose of this research is to examine the influences of political connection and ownership structures towards the tax aggressiveness in Indonesian companies. This research is a quantitative research and the samples consist of the companies listed in the Indonesia Stock Exchange in 2015-2016. Furthermore, the data used in this research is secondary data obtained from the companies' financial reports and annual reports. The tax aggressiveness is measured with Book Tax Differences (BTD) proxy. The result of this research shows that political connection, government ownership, and foreign ownership give negative significant effects towards tax aggressiveness, while institutional ownership give no significant effect towards tax aggressiveness. The limitation of this research is the using of 2-year samples only that consist of companies in various sectors. In addition, the companies that are classified in a particular sector, are given different tax treatment by Directorate General of Taxes. This research can be beneficial for making taxation regulation in the future. This research is also expected to be the supporting literature for the next research for the scholars in the taxation and accounting field related to the company' tax aggressiveness. This research extends the previous research by adding some type of ownership structure in analyzing factors that affect tax aggressiveness in Indonesia. The ownership structure consists of government ownership, foreign ownership, and institutional ownership. Furthermore, political connections in this study were analyzed from connections through boards of directors and commissioners.

Keywords: Book Tax Differences, Ownership Structure, Political Connection, Tax Aggressiveness.
\end{abstract}

\section{Introduction}

Tax has very important role in Indonesia because it is one of the biggest income for the country. Every citizen is required to pay taxes to support the government in the development of public infrastructure and facilities (Gompers \& Metrick, 2001). As what have been mentioned on the www.kemenkeu.go.id, the government expected that by 2017 the tax could contribute to the state's wealth with $85.6 \%$ contribution or Rp. 1498.9 trillion in accordance with State Budget 2017. However, the target decreases from State Budget 2016, which budgeted tax revenue with Rp. 1546.7 trillion. Based on the performance report data published by the Directorate General of Taxation, the percentage of tax revenue realization had decreased continuously from 2013 to 2016. In conclusion, it can be said that there are still many taxpayers both private and business entities that have not maximally fulfilled the tax demands that should be paid to the state.

In the business world, the companies also act as taxpayers who have to pay taxes to the state for the profits they earn. However, the tax payments for some taxpayers are considered as an expense because they do not earn the benefits directly. In addition, the tax payments can also reduce the received and reported profit of the company. It causes many taxpayers who seek to reduce the amount of taxes they have to pay or so-called tax aggressiveness behavior, resulting in the expected tax target as the country revenue decreases. In general, there are many taxpayers who want to pay taxes for small amount because taxes tend to be considered as an expense. In maximizing the corporate value,

* Corresponding author. Email address : zafiagita@gmail.com 
the shareholders tend to want minimizing the corporate tax payments or in other words the shareholders want to act aggressively in optimal way (Hanlon \& Slemrod, 2009).

The main purpose of tax aggressive behavior is to minimize the amount of tax that must be paid by the company. The companies usually try to keep all costs as low as possible in order to earn a higher profit. Therefore, the tax aggressive behavior is considered to enrich the companies and the shareholders because the companies can gain the tax returns that should be paid to the country. The tax aggressive behavior is not an absolute policy undertaken by all companies, but rather relies on the related costs and benefits. It brings significant costs and benefits to the managers, shareholders, and society as a whole (Lanis \& Richardson, 2011). The big amount of tax expense that the companies and the shareholders have to pay to the state enable the shareholders doing tax evasion activities (Chen et al., 2010). However, the corporate tax aggressiveness may cause agency problems because the interests of managers and shareholders may not be in accordance with the tax risks (Wahab, Arif, Marzuki, \& Sanusi, 2017).

There are various factors that can affect the corporate tax aggressiveness. According to Desai and Dharmapala (2009), corporate governance is the determinental factor that needs to be taken into account when the companies engage in tax aggressive behavior, because after doing the tax evasion, the corporate value is expected can increase later. Thus, this research will discuss about several factors that can affect the occurence of tax aggressiveness in Indonesia. Political connection is important to the success of a company with a developing economy (Conyon, He, \& Zhou, 2015). In Asian countries like China, they tend to appoint independent directors who have political connection to assist their activities. The company political connection is usually formed by placing officials, party members or other politicians into the top of the organizational structure of the company. The existence of political connection within the company can affect the policies made to provide benefits to certain parties. The political connection also eases the companies in running their activities because political connection indirectly makes the companies closer to the government.

In addition, there are several previous studies that linked the company's ownership structure as a factor that may influence the corporate tax aggressiveness in previous studies. Previous research was conducted by Adhikari, et al. (2006) suggests that firms with political connections pay taxes on lower ETR values which means having a high degree of tax aggressiveness. The study was supported by several similar studies (Kim and Zhang 2016; Wahab et al., 2017) that have been done in developed (United States) and developing (Malaysia) countries, it concluded the same result where companies with political connections have more tax aggressiveness higher than companies with no political connections. Different results are shown by Fan and Chen's research (2017) in China which concludes that companies with political connections have lower tax aggressiveness than companies with no political connections. Other study conducted in China (Chan, et al., 2013) show results that companies with government holdings have lower tax aggressiveness than private companies. In the other study by Ying, et al. (2017), states that government and institutional ownership has a significant effect on tax aggressiveness. Other study (Khurana \& Moser, 2009) also supports the results of these studies by stating that institutional ownership affects tax aggressiveness. In addition, Annuar, Salihu, \& Obid (2014) proves that the interests of foreign investors have a positive relationship with corporate tax evasion.

Based on the above explanation, this study aims to examine the relation between political connections and ownership structures that consist government ownership, foreign ownership, and institutional ownership toward tax aggressiveness in Indonesia.

\section{Theoretical Framework and Expansion of Hypothesis}

\subsection{Agency Theory}

According to the agency theory perspective, the management company acts as an agent in charge of serving and prioritizing the interests of the owner or principal. 
Agency relations is a contracts between one or more people (principal) with others (agents) to engage in some activities on their behalf which involve delegating authority to the agency in decision making. If the agent prioritizes the fulfillment of their own interests rather than achieving the objectives of the company, it will lead to agency problems. The agency theory is one type of theory that studies the design of contracts to motivate agents to act in the interests of the principal at a time when the agent's interests conflict with the conflict against the principal (Scott, 1997). The company also bear the agency cost of the cost of the company to reduce the existence of agency problems so as to meet the welfare of shareholders. The controlling shareholders can create friction that transforms managers to maximize corporate value, and leads them to focus on decisions that benefit their careers (Bradshaw, et al., 2016).

In this study, agency theory explains the emergence of conflicts between several types of shareholders and the management of the company regarding the payment of taxes on companies in Indonesia. The companies that have political connections to their organizational structures may also cause agency conflicts because political connections to the organizational structure of the company can affect positively and negatively the decisions taken by the company. The Government acts as the party to regulate the state taxation as well as the taxpayer because of its ownership in state-owned enterprises. Agent conflicts occur when the government as a regulator expects taxpayers to pay maximum taxes to the state, but on the other hand management expects a reduction in tax payments to achieve maximum profit. The management company has a view that the company aims to maximize significant profits, one of them is by doing tax planning so that the tax expense that must be paid by the companies low. This difference of view is called conflict of agency between the management company and the government. The agency conflicts can also occur in other types of shareholders such as foreign and institutional shareholders in case of any difference of interest with the management of the company.

\subsection{Tax Aggressiveness}

Tax aggressiveness are various tax planning strategies used to reduce or minimize tax obligations. According to Frank, Lynch, \& Rego (2009), aggressive tax behavior planning has the aim to reduce the amount of taxable profit that can be done in two ways: tax avoidance and tax evasion. Tax avoidance is a legal activity by playing the existing taxation rules, while illegal tax evasion by violating applicable law and legislation can be categorized as tax evasion. Tax avoidance activity is short-term managerial opportunistic behavior that can lead to significant long-term costs (Wahab, et al., 2017).

According to Chen et al. (2010), the obvious advantage of tax aggressiveness is the savings by the companies. Beside to benefiting shareholders, managers may also benefit if they are compensated either directly or indirectly by shareholders for their efforts in effective tax management. However, this activity may incur costs or losses that must be borne by the company in the form of sanctions from tax fiscal. This can affect the image of a declining company and can also affect stock prices. Even the research of Hanlon and Slemrod (2009) concluded that the company's stock price will drop if there is any news about the company's involvement in the tax sheltering activity. Looking at the advantages and disadvantages of tax aggressiveness activities at the company, managers need to carefully consider what actions the company will take.

\subsection{Political Connection}

Political connections are important factors that can have a positive or negative impact on the company. Companies with political connections are companies that indirectly have proximity to the government. A company is said to have a political connection if at least one of its major shareholders (at least owns $10 \%$ of the voting share) or one of the company's top officials (CEO, president, vice president, chairman, secretary) is a member of parliament, minister or closely linked politicians and party members (Faccio, 2007). According to Kim and Zhang (2016), companies are also categorized as having political connections when engaged in political campaigns, and 
lobbying activities. Lobbying refers to actions taken to influence decisions made by government officials.

The companies that have political connections receive greater government and social attention than companies with no political connections, eg CEOs who have political relationships as those who once held office in government are expected to have high moral standards and morally correct acts (Zhang, 2017). The companies with political connections often get special treatment and get various facilities in their operational activities. Based on the research of $\mathrm{Fu}$, et al. (2015), companies with political connections in Indonesia receive preferential treatment from banks in two ways: (1) companies will be easier in lending to state-owned banks, and (2) companies tend to receive full loans from they propose.

\subsection{Ownership Structure}

Companies in running their business require capital in various forms. Investors who invest in the company can also come from various sectors including individuals, private parties and government. The ownership structure is an institution or group that has the largest proportion of share ownership in a company. The ownership structure is considered to affect the course of a company and the management of the organization because each particular group has different motivations in achieving its objectives. The ownership structure within the company can reduce the occurrence of agency problems between the manager and the shareholders. The company shares can be owned by various parties such as institutions, government, foreign investors and others.

In accordance with SFAS No. 15 on Investments in Common Entities and Venture Associations, if an entity directly or indirectly owns $20 \%$ or more of the voting rights, then the entity shall be considered to have significant influence. Significant influence means the power to participate in financial and operational policy decisions but not controlling or jointly controlling the policy. Therefore, ownership is said to affect the significance of the decision to own shares of at least $20 \%$ in the company.

Ownership of shares by foreign investors in the company determines the activities and decisions that will run the company. Foreign investors can bring various influences from the investor's home country to the company where they invest. Aydin and Sayim (2007) argue that empirical studies have shown that multinational corporations perform better than domestic companies when viewed on the basis of ROA values, which means that foreign ownership positively affects the company's financial performance. To achieve the target of national economic development, the government attracts foreign investors to invest in Indonesia in various ways, one of which is tax incentives. Tax incentives in the form of tax holiday and tax allowance given to certain foreign investors can reduce the amount of tax paid by the company. Tax holiday is a tax exemption to be paid for a certain period of time while tax allowance is a reduction of tax rate base.

The institutional ownership of a company is a shareholding by a government agency, a financial institution, a legal entity, a foreign institution and another institution. To increase the value of their investments, institutional shareholders take into account corporate strategy and are often active in corporate governance in order to establish effective governance (Gompers \& Metrick, 2001). Based on Monitoring Theory, institutional ownership plays an important role in reducing agency conflicts between managers and shareholders because of their role as effective monitoring in corporate decision making. The institutional shareholders have the duty to oversee the management of the company so that the company minimizes the profit manipulation action and generates profit according to the rules. The high proportion of institutional ownership reduces the opportunistic behavior of managers because of the larger institutional investors' supervisory efforts. 


\subsection{Development of Hypothesis}

\subsubsection{The Influence of Political Connection Toward Tax Aggressiveness}

Kim and Zhang (2016) stated in previous research that political connections are a valuable source for companies in both developing and developed countries that are important for determining strategic choices of companies. Political connections in companies can actually give a positive and negative influence on tax aggressiveness behavior. On one side, political corporations tend to have closeness with the government so that they operate in harmony with the government's goals in taxation. The government as the party making the tax regulation and the recipient tend to expect the company to maximize payment of corporate taxes to the state. The companies with political connections gain greater social and governmental attention than the companies with no political connections, so it can also encourage companies to act morally right (Zhang, 2017). Therefore, the company will pay the appropriate taxes according to the amount that the company should pay to the state.

On the other hand, Kim and Zhang (2016) also mentioned in their research on several reasons why companies with political connections have higher levels of tax aggressiveness. First, the companies with political connections have lower risk detection rates because they get protection from politicians who are connected to the company. Secondly, the companies with political connections will find it easier to obtain information about changes in tax laws in the future so as to facilitate them in carrying out a more mature tax planning. Some other reasons are companies with political connections have lower market pressure levels in terms of transparency, lower political costs due to tax aggressiveness, and lower risk-taking tendencies. Faccio's research (2010) also states that the companies with political connections enjoy lower tax payments than other companies that are not connected to politics. Based on the above explanation, the proposed hypothesis is as follows:

\section{H1: The company's political connections have a positive effect on tax aggressiveness}

\subsubsection{The Influence of Government Ownership Toward Tax Aggressiveness}

In the companies with government share ownership, the government has a dual role in this regard as a tax regulator that expects the entire community as a taxpayer to fulfill its obligation to pay taxes on the state for the sake of economic development and national infrastructure. On the other hand, the government as the shareholder of the company acts as a taxpayer because it owns part of the company's shares. In the stateowned companies whose shares are the largest held by the government, generally have a goal to maximize their profits one of them through through tax aggressiveness. Fan and Chen (2017) mentioned in their research that state-owned and private companies have different behaviors, for example private companies tend to be more aggressive in maximizing profits compared to state-owned enterprises. SOEs as government companies are not profit-oriented like private companies but prioritize service to the community. As previously mentioned by Fan and Chen (2017). SOEs and non-SOEs tend to have different properties where non-SOE companies tend to aim to maximize corporate profits, while state-owned enterprises fulfill their social and political responsibilities to the state.

In the companies with government ownership, it is often the government that raises, motivates and disciplines managers. The governments also tend to pursue their own goals so often limit the company's ability to maximize the wealth of other shareholders (Chan, Mo, \& Zhou, 2013). On the other hand, private companies have a goal to maximize the wealth of companies and shareholders so that more likely to take aggressive tax action. The differences in the objectives of government-owned and nongovernmental enterprises led to differences in the agency conflicts between the two types of the companies. The state enterprise managers are also more likely to achieve political goals to protect state revenues in corporate tax strategies resulting in lower 
levels of tax aggressiveness than private companies. Based on the above explanation, argumentation appears that private companies are more aggressive in their corporate tax payment compared to SOEs so the proposed hypothesis is as follows:

\section{H2: Government ownership negatively affects tax aggressiveness}

\subsubsection{The Influence of Foreign Ownership Toward Tax Aggressiveness}

Multinational companies are considered to have better performance than domestic companies (Aydin and Sayim, 2007). The Indonesian government is trying to attract foreign investors to invest in Indonesian companies, one of them by providing tax incentives for as a strategy in developing the national economy. The granting of tax incentives to foreign investors under certain conditions enables the emergence of aggressive tax as the government seems to provide allowances for certain companies in tax payments. The government-run tax amnesty program is a sign that many taxpayers especially corporate taxpayers engaged in aggressive taxes using their international relations.

Multinational corporations exploit their international scale to avoid taxes both in the main country and in the country of origin of the investor (Annuar et al., 2014). Developing countries should consider the weakness of foreign investment for the development of the national economy. Based on the explanation, the companies with foreign ownership are estimated to have higher levels of tax aggressiveness, so the authors propose the following hypothesis:

\section{H3: Foreign ownership positively affects tax aggressiveness}

\subsubsection{The Influence of Institutional Ownership Toward Tax Aggressiveness}

Institutional ownership has an important role in monitoring (supervision) so that corporate managers do not take actions that benefit the private. Institutional ownership in developing countries can strengthen the bargaining power of minority stocks and provide oversight in decision making that can benefit major shareholders and managers and directors (Ying et al., 2017). With these external supervisory functions, institutional investors are considered more capable to minimize the existence of earnings management in the company than individual investors. According to Khurana and Moser (2009), institutional shareholders effectively supervise and discipline managers to ensure that they maximize long-term corporate value by preventing aggressive tax behavior.

Ying et al. (2017) also proves in his research that companies with institutional ownership have lower tax aggressiveness especially on long-term institutional ownership. Based on the above explanation, the companies with institutional ownership have low tax aggressiveness, so the proposed hypothesis is as follows:

\section{H4: Institutional ownership negatively affects tax agressiveness}

\section{Research Methodology}

\subsection{Research Design and Data Collection Method}

This research is classified as quantitative research where the data used in this study are in the form of numerical or statements that being scored in number, then are analyzed by using statistic. The data of the current research are the secondary data obtained from books, government' publication regarding economic indicator, census data, statistical abstract, database, media, company' financial statement, etc. In this research, the secondary data were obtained from the financial statement of the companies who are registered in Indonesia Stock Exchange (IDX) on 2015-2016 and other various relevant sources. The data were collected through documentary collection method. This method collects the data based on the category and the classification of written data related to the research which comes from books, magazines, newspapers, internet et Cetera. The data needed for the current study were those related to the 
component of Book-Tax Difference (BTD), company' political connection, company' share ownership, total asset, Return on Asset (ROA), and the type of company' industry. The data of the current research were analyzed by using SPSS 21.

\subsection{The Population and The Sample of The Research}

The population of the current research was the companies which were registered on IDX in 2015 and 2016. The sample was selected in order to observe the tax aggressiveness practice in various industries and sectors. The sample was selected by using purposive sampling technique. It is a sampling technique where the sample was selected based on certain criteria to prevent bias in a study. The selected research sample should meet the following criteria:

a. A company who is registered on IDX in 2015 until 2016.

b. A company who issues audited financial statement in 2015 until 2016.

c. A company who issues a complete financial statement following the data needed for the research.

d. A company who report its financial statement in Rupiah currency.

e. A company who does not experience loss in 2015 until 2016

\subsection{Operational Definition and The Variable Measurement}

\subsubsection{The Dependent Variable}

The dependent variable of the current research was Tax Aggressiveness. Tax Aggressiveness can be measured by several methods such as ETR (Effective Tax Rate), DTAX, BTD (Book-Tax Differences), UTB (Unrecognized Tax Benefit), tax shelter activity, and marginal tax rate. In the current research, tax aggressiveness was measured by using BTD proxy. BTD is measured by using the formula of accounting profit and fiscal profit difference, or by dividing the taxable profit with the total asset (Lin, Tong, \& Tucker, 2014; Gaaya, Lakhal, \& Lakhal, 2017).

$$
\mathrm{BTD}=\frac{\text { Accounting profit }- \text { fiscal profit }}{\text { Total asset }}
$$

\subsubsection{The Independent Variable}

The independent variable of the current research was the company' political connection. It was measured by using dummy variable seen based on the connection possessed by the board of directors and the board of commissioners. A company that possesses political connection is symbolized by 1 , and the company that does not possess political connection is symbolized by 0 in accordance with research conducted by Faccio (2010).

The structure of the ownership comprises government' ownership, foreign ownership, and institutional ownership. They were measured based on the proportion of the company' share ownership. The formula used to determine the share ownership, based on the research conducted by Probohudono, Sudaryono, Sumarta, \& Ardilas (2015) is as follow:

$$
\begin{aligned}
& \text { Government ownership }=\frac{\text { The share owned by the government }}{\text { The total share }} \\
& \text { Foreign ownership }=\frac{\text { The share owned by the foreign investor }}{\text { The total share }} \\
& \text { Institutional ownership }=\frac{\text { The share owned } \text { by the institution }}{\text { The total share }}
\end{aligned}
$$

\subsubsection{Controlling Variable}

In the current research, the controlling variable comprises the company' size, ROA, and the type of the industry. The company size was seen based on the total company asset, the bigger the asset of the company, the bigger the size of such company. That measurement is in line with research conducted by Lin et al. (2014), Their research showed that big companies exhibit more sensitive effect against tax aggressiveness of the company. ROA was measured by dividing net profit by the company' total asset, wherein the research conducted by Lin et.at (2014), was found that it affected the company' tax aggressiveness. The Industry type (IT) was measured 
based on the categorization of industries and sectors on IDX' website, it consisted of main sector, manufacture, and service. Industry type symbolized in dummy variable comprising three types classified as the main sector, manufacture company, and service company. Industry type stated by dummy variable divided into industry type 1 and industry type 2 .

\subsection{Data Analysis Method}

In the current research, the data were analyzed by the following method:

1. Descriptive analysis was done to discover the characteristics of the research variable to be tested.

2. Multiple regression analysis was used to see the test result of the effect of political connection, government ownership, institutional ownership, and foreign ownership on the company' tax aggressiveness. The equation of the current research' regression is as follow:

$\mathrm{TA}=\alpha+\beta_{1} \mathrm{PC}+\beta_{2} \mathrm{GOV}+\beta_{3} \mathrm{FOR}+\beta_{4} \mathrm{INS}+\beta_{5} \mathrm{LOG} \_\mathrm{SIZE}+\beta_{6} \mathrm{ROA}+\beta_{7} \mathrm{IT} 1+$ $\beta_{8} \mathrm{IT} 2+\varepsilon$

Description:

\begin{tabular}{|c|c|}
\hline TA & $=$ Tax Aggressiveness represented by BTD \\
\hline$\alpha$ & $=$ The constant of the regression \\
\hline$\beta$ & $=$ The coefficient of Regression \\
\hline $\mathrm{PC}$ & $=$ Dummy variable of the company' political connection \\
\hline GOV & $=$ The percentage of the company' share owned by the government \\
\hline OR & $=$ The percentage of the company' share owned by the foreign investor \\
\hline INS & $=$ The percentage of the company' share owned by the institution \\
\hline LOG_SIZE & $=$ The logaritma of total asset of the company in a certain year \\
\hline ROA & $\begin{array}{l}=\text { The comparison ratio of net profit towards the company' total asset } \\
\text { in a certain year }\end{array}$ \\
\hline & $=$ The dummy variable of the company' industry type \\
\hline & $=$ The dummy variable of the company' industry type \\
\hline & $=$ The score of error for each individual \\
\hline
\end{tabular}

\section{Result and Discussion}

4.1. Descriptive Statistic

The descriptive statistic aims to discover the character of the research variables. The population of the current research consisted of all company registered in IDX in 2015 and 2016. There were 694 company, the sample of the current research was 360 companies. The selected company was determined by using purposive sampling technique with the criteria were as follow:

Table 1 Sample Selection

The company that was registered in IDX in $2015-2016$

1. Issuing an unaudited financial statement in 2015-2016.

2. Issuing incomplete financial statement or did not issue a financial statement for 2015-2016

3. Issuing a financial statement in foreign currencies in 2015 until 2016.

4. Experiencing loss in 2015-2016

In this research, there were 35 outliers data considered diverging too far from the research data, so those data were removed from the sample of the research. The final sample of the current research was 162 companies for 2015, and 163 companies for 2016 , so the total of the sample was 325 data. 
Political Connection, Ownership Structures and Tax Aggressiveness: The Case of

Table 2 Descriptive Statistic

\begin{tabular}{|c|c|c|c|c|c|}
\hline \multicolumn{6}{|l|}{ PANEL A 2015} \\
\hline Variables & $\mathrm{N}$ & Minimum & Maximum & Mean & Std. Deviation \\
\hline PC 2015 & 162 & 0 & 1 & 0.5000 & 0.5016 \\
\hline GOV 2015 & 162 & 0 & 0.9 & 0.0588 & 0.1874 \\
\hline FOR 2015 & 162 & 0 & 0.98 & 0.3351 & 0.3049 \\
\hline INS 2015 & 162 & 0 & 1 & 0.6492 & 0.2768 \\
\hline LOG_SIZE 2015 & 162 & 10.72 & 14.96 & 12.5833 & 0.8391 \\
\hline ROA 2015 & 162 & 0 & 0.26 & 0.0506 & 0.0483 \\
\hline IT1 2015 & 162 & 0 & 1 & 0.2840 & 0.4523 \\
\hline IT2 2015 & 162 & 0 & 1 & 0.6543 & 0.4771 \\
\hline \multicolumn{6}{|l|}{ PANEL B 2016} \\
\hline Variables & $\mathrm{N}$ & Minimum & Maximum & Mean & Std. Deviation \\
\hline PC 2016 & 163 & 0 & 1 & 0.5031 & 0.5015 \\
\hline GOV 2016 & 163 & 0 & 0.9 & 0.0587 & 0.1875 \\
\hline FOR 2016 & 163 & 0 & 0.98 & 0.3227 & 0.3011 \\
\hline INS 2016 & 163 & 0 & 1 & 0.6475 & 0.2795 \\
\hline LOG_SIZE 2016 & 163 & 10.79 & 15.02 & 12.6449 & 0.8363 \\
\hline ROA 2016 & 163 & 0 & 0.27 & 0.0485 & 0.0426 \\
\hline IT1 2016 & 163 & 0 & 1 & 0.2822 & 0.4515 \\
\hline IT2 2016 & 163 & 0 & 1 & 0.6626 & 0.4743 \\
\hline \multicolumn{6}{|c|}{ PANEL C POOLED } \\
\hline Variables & $\mathrm{N}$ & Minimum & Maximum & Mean & Std. Deviation \\
\hline PC & 325 & 0 & 1 & 0.5015 & 0.5008 \\
\hline GOV & 325 & 0 & 0.9 & 0.0587 & 0.1872 \\
\hline FOR & 325 & 0 & 0.98 & 0.3289 & 0.3026 \\
\hline INS & 325 & 0 & 1 & 0.6483 & 0.2777 \\
\hline LOG_SIZE & 325 & 10.72 & 15.02 & 12.6142 & 0.8370 \\
\hline ROA & 325 & 0 & 0.27 & 0.0495 & 0.0455 \\
\hline IT1 & 325 & 0 & 1 & 0.2831 & 0.4512 \\
\hline IT2 & 325 & 0 & 1 & 0.6585 & 0.4750 \\
\hline
\end{tabular}

Note: $\mathrm{PC}=$ Political connection, GOV=Government ownership, FOR=Foreign ownership, INS=Institutional ownership, LOG_SIZE= company’ size, ROA= Return On Assets, IT1=Industry type 1, IT2=Industry type 2

\section{Source: Organized secondary data}

Based on Table 2, it can be seen that on Panel A 2015, the political connection showed 0.5000 as the mean score and gained insignificant increase as it is shown by Panel B 2016 by 0.5031 , so the score on the Panel Pooled was 0.5015 . The minimum and maximum score exhibited same number, zero for the minimum score, and 1 for the maximum score. GOV on Panel A 2015 showed 0.0588 as its mean score, while, in 2016, its score was 0.0587. It means that there was no significant increase from the previous year. Therefore, the mean score in panel pooled was 0.0587. The minimum and maximum score of 2015 and 2016 showed the same number, 0 and 0.90 , so the score in panel Pooled also showed 0 for the minimum score and 0.90 for the maximum score.

FOR showed an insignificant decrease of the mean score by 0.3351 for 2015 and 0.3227 for 2016, so the mean score of the panel Pooled showed 0.3289 as its score. The minimum and maximum score of 2015 and 2016 showed the same number, 0 for the minimum score and 0.98 for the maximum score, therefore, the score in panel Pooled also showed the same number. INS experienced a slight increase of the mean score by 0.6942 for 2015 and 0.6475 for 2016, so the mean score in the panel Pooled was 0.6483 . The minimum and maximum score exhibited same number, zero for the minimum score, and 1.00 for the maximum score. 
The controlling variable on table 1 comprised the company' size (LOG_SIZE), Return On Asset (ROA), and the Industry Type (IT). LOG_SIZE showed the mean score experiencing increase, in 2015 it was 12.5833 which then became 12.6449 , so the mean score in the panel Pooled was 12.6142. The maximum score experienced increase, in 2015 it was 14.96, and in 2016 it was 15.02 so the score in the panel Pooled showed 15.02. ROA showed that the mean score of 2015 was 0.0506 and increase to be 0.0485 in 2016, so the mean score in the panel Pooled was 0.0495. The maximum score of 2015 was 0.26 and 0.27 in 2016, so the score in the panel Pooled showed 0.27 as its score. Industry Type 1 experienced a decrease of the mean score wherein 2015, it showed 0.2840 as the score, and in 2016 , it showed 0.2822 as the score, so the score of the panel pooled was 0.2831 . Industry Type 2 experienced a decrease of the mean score wherein 2015, it showed 0.6543 as the score, and in 2016, it showed 0.6626 as the score, so the score of the panel pooled was 0.6585 .

4.2. The result of Regression Test.

Table 3 The Result of Regression Test

\begin{tabular}{|c|c|c|c|c|c|}
\hline Variables & Year & $\mathbf{N}$ & Mean & $\mathbf{t}$ & Sig. \\
\hline \multirow{3}{*}{$\mathrm{PC}$} & 2015 & 162 & 0.5000 & & \\
\hline & 2016 & 163 & 0.5031 & -1.823 & $* * * 0.069$ \\
\hline & Total & 325 & 0.5015 & & \\
\hline \multirow{3}{*}{ GOV } & 2015 & 162 & 0.0588 & & \\
\hline & 2016 & 163 & 0.0587 & -3.531 & $* 0.000$ \\
\hline & Total & 325 & 0.0587 & & \\
\hline \multirow{3}{*}{ FOR } & 2015 & 162 & 0.3351 & & \\
\hline & 2016 & 163 & 0.3227 & -3.537 & $* 0.000$ \\
\hline & Total & 325 & 0.3289 & & \\
\hline \multirow{3}{*}{ INS } & 2015 & 162 & 0.6492 & & \\
\hline & 2016 & 163 & 0.6475 & .060 & 0.952 \\
\hline & Total & 325 & 0.6483 & & \\
\hline \multirow{3}{*}{ LOG_SIZE } & 2015 & 162 & 12.5833 & & \\
\hline & 2016 & 163 & 12.6449 & 2.561 & $* * 0.011$ \\
\hline & Total & 325 & 12.6142 & & \\
\hline \multirow{3}{*}{ ROA } & 2015 & 162 & 0.0506 & & \\
\hline & 2016 & 163 & 0.0485 & 21.551 & $* 0.000$ \\
\hline & Total & 325 & 0.0495 & & \\
\hline \multirow{3}{*}{ IT1 } & 2015 & 162 & 0.2840 & & \\
\hline & 2016 & 163 & 0.2822 & .798 & 0.425 \\
\hline & Total & 325 & 0.2831 & & \\
\hline \multirow{3}{*}{ IT2 } & 2015 & 162 & 0.6543 & & \\
\hline & 2016 & 163 & 0.6626 & 3.452 & $* 0.001$ \\
\hline & Total & 325 & 0.6585 & & \\
\hline
\end{tabular}

*significant at $1 \%$ level, ** significant at 5\% level, *** significant at $10 \%$ level

Note: $\mathrm{PC}=$ Political connection, GOV=Government ownership, FOR=Foreign ownership, INS=Institutional ownership, LOG_SIZE= company' size, ROA= Return On Assets, IT1=Industry type 1, IT2=Industry type 2 Source: Organized secondary data

Based on the result of regression test in table 3, PC showed the significance score by 0.069 or significant at $10 \%$. It means that the political connection negatively affected the dependent variable. GOV showed 0.000 as its significance score which means that such variable is significant on the level of $1 \%$, so the government ownership negatively affected the dependent variable. FOR showed 0.000 as its significance score which means that such variable is significant on the level of $1 \%$, so the foreign ownership negatively affected the dependent variable. INS showed 0.952 as its significance score, so the institutional ownership did not affect the dependent variable. Grounded on table 2 , it could be concluded that the political connection, government ownership, and 
foreign ownership negatively affected the tax aggressiveness, while institutional ownership did not affect tax aggressiveness,.

LOG_SIZE showed 0.011 as its significance score which means company size positively affected the dependent variable. ROA showed 0.000 as its significance level which means that it was significant on the level of $1 \%$. Such result showed that ROA positively affected the dependent variable. IT 1 showed 0.425 and 0.001 for IT2 as its significance level. Such result showed that industry type 1 did not affectthe dependent variable, while the industry type 2 positively affected the dependent variable. Based on that test, it could be concluded that the company' size, ROA and Industry type positively 2 affected tax aggressiveness.

Table 4 The Result of Regression Test based on Year

\begin{tabular}{|c|c|c|c|c|c|}
\hline \multicolumn{6}{|c|}{ PANEL A 2015} \\
\hline Variables & Year & $\mathrm{N}$ & Mean & $\mathrm{t}$ & Sig. \\
\hline $\mathrm{PC}$ & 2015 & 162 & 0.5000 & -1.733 & $* * * 0.085$ \\
\hline GOV & 2015 & 162 & 0.0588 & -2.094 & $* * 0.038$ \\
\hline FOR & 2015 & 162 & 0.3351 & -2.213 & $* * 0.028$ \\
\hline INS & 2015 & 162 & 0.6492 & -0.146 & 0.884 \\
\hline LOG_SIZE & 2015 & 162 & 12.5833 & 1.685 & $* * * 0.094$ \\
\hline ROA & 2015 & 162 & 0.0506 & 17.156 & $* 0.000$ \\
\hline IT1 & 2015 & 162 & 0.2840 & 0.581 & 0.562 \\
\hline IT2 & 2015 & 162 & 0.6543 & 2.510 & $* * 0.013$ \\
\hline \multicolumn{6}{|c|}{ PANEL B 2016} \\
\hline Variables & Year & $\mathrm{N}$ & Mean & $\mathrm{t}$ & Sig. \\
\hline $\mathrm{PC}$ & 2016 & 163 & 0.5031 & -0.510 & 0.611 \\
\hline GOV & 2016 & 163 & 0.0587 & -3.037 & $* 0.003$ \\
\hline FOR & 2016 & 163 & 0.3227 & -2.876 & $* 0.005$ \\
\hline INS & 2016 & 163 & 0.6475 & 0.166 & 0.868 \\
\hline LOG_SIZE & 2016 & 163 & 12.6449 & 1.989 & $* * 0.048$ \\
\hline $\mathrm{ROA}$ & 2016 & 163 & 0.0485 & 12.324 & $* 0.000$ \\
\hline IT1 & 2016 & 163 & 0.2822 & 0.537 & 0.592 \\
\hline IT2 & 2016 & 163 & 0.6626 & 2.295 & $* * 0.023$ \\
\hline
\end{tabular}

*significant at $1 \%$ level, $* *$ significant at $5 \%$ level, $* * *$ significant at $10 \%$ level

Note: $\mathrm{PC}=$ Political connection, GOV=Government ownership, FOR=Foreign ownership, INS=Institutional ownership, LOG_SIZE = company' size, ROA= Return On Assets, IT1=Industry type 1, IT2=Industry type 2

Source: Organized secondary data

Based on table 4 Panel A 2015, PC showed significance score by 0.085 or significant on the $10 \%$ level, so the political connection negatively affected the dependent variable. GOV showed 0.038 as its significance score, so government ownership negatively affected the dependent variable. FOR showed 0.028 as its significance score or significant at $5 \%$ level, so the foreign ownership negatively affected the dependent variable. INS showed 0.884 as its significance score or is above the $10 \%$ significance level, so the institutional ownership did not affect the dependent variable. LOG_SIZE, ROA and IT2 showed positively affected the dependent variable, while IT1 did not affect the dependent variable.

Based on Data Panel B 2016, PC showed significance score by 0.611 which is above the $10 \%$ significance level, so the political connection did not affect the dependent variable. GOV showed 0.003 as its significance score which significant at $1 \%$ level, so the government ownership negatively affected the dependent variable. FOR showed 0.005 as its significance score which or was significant on the level of 
$1 \%$, so the foreign ownership negatively affected the dependent variable. INS showed 0.868 as its significance score or was above the $10 \%$ significance level, so the institutional ownership did not affect the dependent variable. LOG_SIZE, ROA and IT2 positively affected the dependent variable, while IT1 did not affected the dependent variable.

Based on table 3, it could be concluded that the result of regression test based on year showed different result. On the data of panel A 2015, the political connection, government ownership, and foreign ownership negatively affected tax aggressiveness, while institutional ownership did not affect tax aggressiveness. The controlling variable namely the company size, ROA and the Industry Type 2 positively affected tax aggressiveness. On the data of panel B 2016, political connection and institutional ownership did not affect tax aggressiveness, while the government ownership and foreign ownership negatively affected tax aggressiveness. The company' size, ROA and Industry type 2 positively affected tax aggressiveness.

\subsection{Discussion}

Based on the result of the research, political connection negatively affecyed tax aggressiveness. It shows that $\mathrm{H} 1$ which states that political connection positively affects tax aggressiveness is rejected. These results are in accordance with previous research by Fan and Chen (2017) where political connections negatively affected tax aggressiveness. Political connections are considered to have close ties with the government, so that companies with political connections are considered to act in accordance with government goals and regulations. However, that result is in contrast with some previous research (Adhikari, et al., 2006; Kim and Zhang (2016); Wahab et al. (2017)) which states that a company with political connection possesses significant positive correlation towards tax aggressiveness.

The government ownership shows significant negative relationship towards tax aggressiveness, which means that $\mathrm{H} 2$ is accepted. That result is in line with previous research conducted by Chan et al. (2013) where a company with non-government ownership possess more significant tax aggressiveness. A company with government ownership hold aims which tend to be in line with the government' policy since it does not only profit-oriented. The government takes dual role, as the tax regulator, and the company shareholder who becomes the taxpayer tends not to perform tax aggressiveness.

Foreign ownership also shows a significant negative result against tax aggressiveness. It means that Hypothesis 3 (H3) which states that foreign ownership positively affects tax aggressiveness is rejected. This result is different from the research conducted by Annuar et al. (2014) which proved that the foreign investors' interest resulted in the significant positive effect on the company' tax aggressiveness. It exhibited the possibility that a multinational company takes advantages from its international operational scale to avoid tax either in its own country or its foreign investors' country.

Institutional ownership did not affect tax aggressiveness, which means that Hypothesis 4 (H4) which states that institutional ownership negatively affects tax aggressiveness is rejected. This result is in contrast with some previous researchers (Khurana \& Moser, 2009; Ying et al., 2017) which stated that institutional ownership holds a significant relationship with tax aggressiveness.

Grounded on the result of the year based-regression, 2015 shows same result from the regression result of the data pooled, where political connection, government ownership, foreign ownership shows significant negative relationship with tax aggressiveness. Institutional ownership did not affected tax aggressiveness. The regression result for 2016 shows different result with the regression on panel pooled, where political connection and institutional ownership did not affect tax aggressiveness, while government ownership and foreign ownership negatively affected tax aggressiveness. 


\section{Conclusion, Implication, and Limitation}

\subsection{Conclusion}

This research aimed at testing the effect of political connection and the share ownership structure comprising government ownership, foreign ownership, and institutional ownership on tax aggressiveness. Based on the sample consisting of the companies registered in IDX in 2015-2016, this research concludes that political connection and the ownership structure affects tax aggressiveness. The political connection, government ownership, and the foreign ownership shows a significant negative relationship against tax aggressiveness. However, institutional ownership show insignificant relationship against tax aggressiveness.

\subsection{Research Implication}

The current research is expected to be a feedback for the government, particularly the Directorate General of Tax regarding tax aggressiveness performed by the taxpayers, in this case, are the companies in Indonesia. So this research can be beneficial for making taxation regulation in the future. This research is also expected to be the supporting literature for the next research for the scholars in the taxation and accounting field related to the company' tax aggressiveness.

\subsection{Limitation and Suggestion}

This research is using of 2-year samples only that consist of companies in various sectors. In addition, the companies that are classified in a particular sector, are given different tax treatment by Directorate General of Taxes. For the next researcher, it is suggested to select the more specified sample from specific industry type and sector or to exclude the company who gains special treat from the Directorate General of Tax from the sample list. Besides, tax aggressiveness in the current research is only measured by normal proxy of BTD. For the next research, it will be better to add Abnormal Book-Tax Difference (ABTD) as a proxy along with BTD or to compare to the general measurement Effective Tax Rate (ETR) which is frequently used in the previous research.

\section{References}

Adhikari, A., Derashid, C., \& Zhang, H. (2006). Public policy, political connections, and effective tax rates: Longitudinal evidence from Malaysia. Journal of Accounting and Public Policy, 25(5), 574-595.

Annuar, H. A., Salihu, I.A., \& Obid, S.N.S. (2014). Corporate ownership, governance and tax avoidance: An interactive effects. Procedia-Social and Behavioral Sciences, 164, 150-160.

Aydin, N., \& Sayim, M. (2007). Foreign ownership and firm performance: Evidence from Turkey. International Research Journal of Finance and Economics, 11, 103111.

Bradshaw, M., Liao, G., \& Ma, M. (2016). Ownership structure and tax avoidance: Evidence from agency costs of state ownership in China.

Chan, K. H., Mo, P. L. L., \& Zhou, A.Y. (2013). Government ownership, corporate governance and tax aggressiveness: evidence from China. Accounting \& Finance, 53(4), 1029-1051.

Chen, S., Chen, X., Cheng, Q., \& Sevlin, T. (2010). Are family firms more tax aggressive than non-family firms?. Journal of financial economics, 95(1), 41-61. 
Conyon, M. J., He, L., \& Zhou, X. (2015). Star CEOs or political connections? Evidence from China's publicly traded firms. Journal of Business Finance \& Accounting, 42(3-4), 412-443.

Desai, M. A., \& Dharmapala, D. (2009). Corporate tax avoidance and firm value. The review of Economics and Statistics, 91(3), 537-546.

Faccio, M. (2007). The characteristics of politically connected firms. Purdue CIBER Working Papers, Paper 51.

Faccio, M. (2010). Differences between politically connected and nonconnected firms: A cross-country analysis. Financial management, 39(3), 905-928.

Fan, H., \& Chen, L. (2017). Politically Connected Independent Directors and Effective Tax Rates in China. Asian Journal of Finance \& Accounting, 9(1), 333-350.

Frank, M. M., Lynch, L. J., \& Rego, S. O. (2009). Tax reporting aggressiveness and its relation to aggressive financial reporting. The Accounting Review, 84(2), 467-496.

Fu, J., Shimamoto, D., \& Todo, Y. (2015). Can Firms with Political Connections Borrow More Than Those Without? Evidence from Firm-Level Data for Indonesia. Research Institute of Economy, Trade and Industry (RIETI).

Gaaya, S., Lakhal, N., \& Lakhal, F. (2017). Does family ownership reduce corporate tax avoidance? The moderating effect of audit quality. Managerial Auditing Journal.

Gompers, P. A., \& Metrick, A. (2001). Institutional investors and equity prices. The quarterly journal of Economics, 116(1), 229-259.

Hanlon, M., \& Slemrod, J. (2009). What does tax aggressiveness signal? Evidence from stock price reactions to news about tax shelter involvement. Journal of Public Economics, 93(1), 126-141.

Khurana, I. K., \& Moser, W. J. (2009). Institutional ownership and tax aggressiveness.

Kim, C. F., \& Zhang, L. (2016).Corporate political connections and tax aggressiveness.Contemporary Accounting Research, 33(1), 78-114.

Lanis, R., \& Richardson, G. (2011). The effect of board of director composition on corporate tax aggressivenes. Journal of Accounting and Public Policy, 30(1), 507.

Lin, S., Tong, N., \& Tucker, A. L. (2014). Corporate tax aggression and debt. Journal of Banking \& Finance, 40, 227-241.

Probohudono, A. N., Sudaryono, E. A., Sumarta, N. H., \& Ardilas, Y. (2015). Ownership, corporate governance and mandatory tax disclosure influencing voluntary financial disclosure in Indonesia. Corporate Ownership \& Control, 13(1).

Scott, W. R. (1997). Financial Accounting Theory. USA: Prentice Hall International.

Wahab, E. A. A., Arif, A. M., Marzuki, M. M., \& Sanusi, Z. M. (2017). Political connections, corporate governance, and tax aggressiveness. Asian Review of Accounting.

Ying, T., Wright, B., \& Huang, W. (2017). Ownership structure and tax aggressiveness of Chinese listed companies. International Journal of Accounting \& Information Management, 25(3), 313-332. 
Political Connection, Ownership Structures and Tax Aggressiveness: The Case of Indonesia

Zhang, C. (2017). Political connections and corporate environmental responsibility: Adopting or escaping?. Energy Economics, 68, 539-547. 